\title{
INNOVATIONS IN REGIONAL JOURNALISM (ON THE EXAMPLE OF MASS MEDIA OF THE REPUBLIC OF TATARSTAN)
}

\author{
Tatiana A. Nagovitsyna ${ }^{1}$ \\ Ramis R. Gazizov²
}

\begin{abstract}
The article refers to the "new media" of the regional level - the Republic of Tatarstan. A characteristic of "new media" is given and an analysis is made of the effective use of three of their types - video blogs, blogs and online conferences. In the article the specifics of Internet publications are researched on the material of the leading regional mass media of the Republic of Tatarstan: Inde, Real Time, ProKazan.ru, Business Online, their characteristics are given, comparative analysis is carried out, attention is paid and evaluated the nature of innovations being introduced into the activities of publications.System characteristics of regional mass media on the Internet are a system that can be classified on the basis of: ownership (public and private media), information policy (pro-state and opposition). They
\end{abstract}

also have differentiation, depending on the direction, the problems to be reflected.The trend of modernity is the emergence of a large number of information publications, prevailing over analytical publications, over expert opinions. Most publications on the Internet create commercial structures interested in advertising revenue, as well as in managing the information environment at the level of a specific region of the Russian Federation. In this material materials of the Republic of Tatarstan are investigated.

Keywords: regional journalism, mass media Republic of Tatarstan.

\section{Introduction \\ Today we can say with confidence that journalism, including regional, is undergoing serious changes.}

1 Kazan Federal University, Kremliovskaya Russian Federation. E-mail: nagovitsinatatyana@mail.ru. gazizov-da@yandex.ru. 2 Kazan Federal University, Kremliovskaya Russian Federation. E-mail: nagovitsinatatyana@mail.ru. gazizov-da@yandex.ru. 
In the everyday life of theorists and practitioners of Russian journalism, the term "new media" has now become firmly established. This term appeared relatively recently - at the end of the twentieth century. Meanwhile, the definition of "new" is very conditional. It does not express any specific qualities of the media, except its status of recent actualization. The main properties of new media are: interactivity, digital nature, and new communication opportunities. Let's take a closer look at each separate characteristic of new media,

The first characteristic feature is interactivity. It underlies new media. Its appearance is directly connected with the rapid growth of the development of the Internet, the globalization of the information space and convergence.

The second feature is the digital format. At the end of XX century. observes the emergence and development of digital, computer, information, network technologies and communications. Convenience for consumers of information here primarily lies in the mobility of media. They are willing to pay for fast and high-quality content.
The third feature is multimedia. As D. Yu. Kulchitskaya writes, the scope of the concept of convergence includes the notion of multimedia [1, p.13]. Since the 1980s, the name of multimedia has changed, when the name "audio-videocomputer" was used to designate a device adapted for recording on discs. And already in the 1900s, the expression "true multimedia" became "true multimedia" [2, c.11]. Multimedia is not only the quality of digital space, but also the format in which there are modern online media. Multimedia combines different means and forms of communication. [3, p. 37].

It is necessary, meanwhile, not to confuse the notion of "digital media" and "new media". According to D.V. Galkin, the world of new media includes: Internet sites, virtual reality of multimedia, computer games, interactive installations in art, computer animation, digital video, cinema and the humancomputer interface. [4] Among the fundamental factors here it is necessary to allocate: the degree of quality of media content, the breadth of coverage of the existing and potential audience, how to disseminate information and attract new audiences, and others. 


\section{Methods}

The research is based on the structural-functional, content, comparative-comparative methods of analysis, which made it possible to reveal the essential features of the specifics of blogs in the publication. Multimedia features of the media are widely studied by a wide range of international scientists $[7 ; 8 ; 9]$.

The authors proceed from a comprehensive substantiation of the issue under study, analyze journalistic texts published in 2017. The materials are prepared by professional authors, journalists, editors, not by experts and not by scientists, which is fundamentally important when differentiating approaches and positions in relation to the reality reflected [10].

First, it is worth giving a characterization to the research publications: the newspapers "Real Time", "BUSINESS Online", as well as to the information agency "Tatarinform".

The newspaper "Real time". The project is about business news and industry analyst realnoevremya.ru. Upto-date information on the development of the economy and technologies in the
Volga Federal District for regional, federal and foreign readers.

The newspaper "BUSINESS Online". This is the most cited regional media of the Republic of Tatarstan in the last three years. The publication is valid for 10 years, has regular readers. The circle of the audience consists of representatives of the regional establishment, business circles, representatives of big business. In the information policy of the publication, the highest priority is given to companies interested in promoting goods for business and consumers with high incomes. The project has no equal in the coverage of a high-quality audience in the country. According to the research of the sociological company CIAR 2015, "BUSINESS Online" is read by about $80 \%$ of executives in Kazan and about $70 \%$ of managers in Naberezhnye Chelny. At the same time, BUSINESS Online is the most popular regional media for more than half of Kazan's business audience and almost $30 \%$ of the business community of Naberezhnye Chelny. The publication is considered economically successful and independent, its founders do not include 
state structures and large business groups.

The newspaper "BUSINESS Online" is recognized as the best regional publication on the results of the annual All-Russian competition of business journalism of the Russian Union of Industrialists and Entrepreneurs (RUIE) in 2013.

Information agency "Tatarinform". Has been in operation since 1990. It is considered the first independent regional news agency in the Soviet Union and in the Russian Federation. Today it is the leading news agency of the Republic of Tatarstan.

\section{Results}

As of the beginning of 2017 in the Republic of Tatarstan, 1.3 thousand media were registered. Today, the total number of Internet users in our republic is about 3 million people, more than half of whom visit the network every day. At the same time, it is too early to speak about the active growth of the Internet audience, and therefore most of the websites of Internet publications. The increase in subscribers, in our opinion, will be schoolchildren and people older than 50 years. But, it is worth emphasizing that the Internet publications themselves are more and more oriented towards the youth of 1830 years (Internet publications «Inde», «Real time») and people aged 35 plus (Internet publications «ProKazan.ru». «Tatar-inform», business newspaper «Business Online»). Most Internet publications develop their projects, usually through social networks. Interesting, in our opinion, was the project «Tom Sawyer Fest - Let's At Home».

If we talk about the rating of the Internet media of the Republic of Tatarstan, according to the information of medialogy, starting from the first quarter of 2017 to the present, the list of leaders of the republican electronic mass media includes: Tatar-Inform, Business Online, Real time.

The information agency Tatarinform delivers various modern media products to the media market, including new media-video interviews, online broadcasts and online conferences. In recent years, the agency has built a new system of work in social networks. Currently, social media hosts more than 100 regional and federal news every day. In April 2017, the Tatar-inform news 
agency received a million unique readers.

\section{Discussion}

Video blogs are one of the specific types of new media that are experiencing a period of rapid development. The video blog materials should have a targeted focus and be regularly placed as video content on one of the popular video hosting platforms, using the potential of social networks.

Let's look at some examples of video blogs and blogs. Up to 50 thousand views are picked up by clips of the Kazan video blogger Sergei Koepp, which this year has become quite popular among users of different ages the Internet. The plot of his video blog, at first glance quite simply - the author simply buys popular dishes in fast food establishments in Kazan and eats them directly to the camera in his car. This video blog can cause the audience to have different emotions. Can be perceived or not perceived by them. However, judging by the number of views, this video blog is considered in demand.

Another example is the live magazine of kukmor Niyaza Aksanova
(Kukmor, Republic of Tatarstan). It is read by more than fifteen thousand people. Kukmor was one of the organizers of the Kazan action "Bloggers against garbage", which in an improved and modified version will be held this year.

Niyaz Aksanov writes about his impressions of attending various events. In our opinion, he obviously lacks the "author's self." On this example, one can trace the connection. It should be noted that the author regularly responds to all comments and often comments on the entries in the journals of his Internet Among the latest Niyaz records, I would like to especially highlight the photo report about the trip to Kazakhstan.

You should also mention the blogs irek_murtazin, mamonino, mamonino,. marat_ahtjamov, etc. They are led by journalists, businessmen, and just people who try themselves in this sphere.

G.P. Bakulev [6, p.135] singles out the main features distinguishing "new" media from "old" ones:

1. Decentralization - the supply of information topics and the forms of their submission are no longer dependent 
on their suppliers, they are offered by the readers themselves

2. Large coverage of the audience is due to modern technologies.

3. Interactivity of new media allows the recipient of information to the user and exchange it with those to whom it is interesting.

4. Flexibility of form, content and use.

A successful example of online conferences, in our opinion, is the online edition of "Real Time. Kazan. "Let us dwell on some of them. August 25, 2017 - online conference with the Mayor of Naberezhnye Chelny, Nailym Magdeev. September 7, 2017 - online conference with Dariya Bikbaeva, businesswoman, head of the marriage agency.

In the first case, Nail Magdeev described how his experience in managing Bugulma in the 1990s helped bring Naberezhnye Chelny out of the crisis of 2014, establish a proper level of work there, why he considers the work of the mayor more difficult than the work of the minister. This material may be of interest to a fairly wide audience from 20 to 70 years. The format of the video not only promotes a better mastering of the topic, but also gives the opportunity to participate in the dialogue. The choice of the main guest of the online conferencethe Mayor of Naberezhnye Chelny-is an interesting and unusual person.

From the materials of the second online conference it was possible to find out what is the basis of business creativity, can a woman successfully conduct business and what is needed for this "and all about the wedding" on a turn-key basis "in the agency of Dariya Bikbaeva [7]. Despite the fact that this material refers to the "female" theme, it was also interesting to a large and diverse audience and had thousands of views.

As the brief analysis shows, online conferences are an effective way to increase the effectiveness of the impact of publications on a certain readership and the formation of public opinion. The direct participation of Internet users in the online conferences held by any publication makes them accomplices, people interested in the ultimate goal of solving the problems raised. Online conferences introduce subscribers to modern forms of journalistic materials.

\section{Summary}


During the work on the article, various sources of domestic and foreign scientific literature on the problems of journalism and new media were used and analyzed, in particular, materials of forums and conferences, as well as directly the media of the Republic of Tatarstan. Today, among the scientists practicing the theme of the new mass media, it is worth mentioning D. Bryant, S. Thompson, B. Etling, GP Bakuliev, P. S. Kireev, and others.

As a result of the study, the authors concluded that effective use of new media increases the number of subscribers and makes publications popular. Recently, new media have constructed new realities. New mass media can be successfully used not only in journalism, but also in related specialties - public relations, sociology, psychology, etc.

\section{Conclusion}

Further research of the functioning of Internet publications can be carried out in the directions of determining their system-functional, linguistic, stylistic, genre specificities. Comparative analysis of the activity of publications of different cities, regions, countries is expedient. Differentiation can occur and proceeding from the specialization of publications, their problem-thematic focus.

\section{Conflict of interest}

The authors confirm that the data is not contained in the conflict.

\section{Acknowledgments}

The work is carried out in accordance with the Federal Government's Program of Competitive Growth of Kazan Federal University.

\section{References}

Bakulev G.P. Mass Communication: Western Theories and Concepts: Proc. allowance. - Moscow: Aspect Press, 2005. - $176 \mathrm{p}$.

Galkin D.What is new media [Electronic resource]. Available on: URL: Mediahttp://rwr.ru/forum/topic31434.ht $\mathrm{ml})$ (access mode is free).

"Kazan portal" from June 27, 2017 [Electronic resource]. Available on: URL: https: 
//news.rambler.ru/community/37254251

-v-tatarstane-rabot. (Access mode - free).

Kachanov D.G. Development of the concept of "Mudedmedia" as a form of communication. Moscow State University, 2017.

Kulchitskaya D. Yu. Convergence and Multimedia: points of intersection and differences // Media almanac. - 2014. No. 6. - P. 12-16.

Novoseltsev SK Multimedia - synthesis of three elements / S.K. Novoseltsev // Computer-press. - 1991. - No. 7. - P. 314.

Nowson, S. The language of weblogs: a study of genre and individual differences. PhD Thesus (Unpublished manuscript) [Text] // S. Nowson. University of Edinburgh, 2006. - P. 279.

Thurlow, C. The Internet and Language [Text] // C. Thurlow. - Concise Encyclopedia of Sociolinguistics, Elsaivier, 2001

Gazizov R.R. On the issue of moral and ethical regulation of manipulative processes in journalism // Contemporary communicative space of journalistic science, practice and education: contours and reality of new media. Issue 5: a collection of scientific articles / ed. V.Z. Garifullina, E.S. Doroschuk. - Kazan: Kazan. Univ., 2014. - P. 20-27.

Herring S. C. Bridging the gap: A genre analysis of weblogs [Text] // L. A. Scheidt, S. Bonus, E. - Wright Proceedings of the 37th Hawaii International Conference on System Sciences, 2004 